\title{
The Phenomenon of "Russian Soul" as a Reflection of Traditional Russian Conservatism: New Theoretical and Methodological Approaches and Ordinary Perception of Conservatism
}

\author{
Alexander Mikhaylovich Fedulov ${ }^{1}$ \\ Svetlana Gennadyevna Karepova ${ }^{1}$ \\ Karabulatova Irina Sovetovna1 \\ Bigaysha Zeynulyevna Akhmetova² \\ Ramil Safievich Istamgalin² \\ 1/nstitute of Social and Political Research of the Russian Academy of Sciences, 32A, Leninsky prospect, Moscow \\ 2Ufa state University of Economics and service
}

Doi:10.5901/mjss.2015.v6n6s3p113

\section{Abstract}

\begin{abstract}
The modernization changes happening in Russia since the beginning of the 90th of the XX century designated deep division of society and power. The wave of public performances, which is lasting since December 2011 and decreased, but completely did not disappear now in Russia, found a certain extent of misunderstanding and mutual distrust. The special role in the course of formation consolidating society spiritually - moral and socially - political bases is allocated for conservatism as conservative function of the state consists in association of the people in social space, and involvement of social thought of apologists of the Russian conservatism allows to carry out this association. Traditional Russian conservatism is considered as essential part mysterious "the Russian soul" that defines life of the Russian person both in the native environment (Anisimov \& Gulyaihin, 2013; Karabulatova, Koyche \& Gultyaev, 2013; Karabulatova \& Polivara, 2013; Karabulatova, Sayfulina \& Akhmetova, 2013 \& Karabulatova \& Akhmetova 2015). The phenomenon of "mysterious Russian soul" is known as a hackneyed stamp, a stereotype around the world, causing firm interest from residents of the countries and the West and East. Authors believe, that existing "scissors" in perception of mentality of the Russian people are the starting mechanism for the distorted portrait of Russians, but also influence a choice of the preferred strategy and tactics in communication with Russians therefore both parties sustain losses of the material and moral plan. The authors provided analysis of existing concepts and concluded to megalocephaly and poly aspartate Russian conservatism as such.
\end{abstract}

Keywords: conservatism, phenomenology, philosophy and sociology of culture, conservatism typology, mentality.

\section{Introduction}

Exclusiveness of any people, ethnos and nation is the main axiom, which demands from us studying of those exclusive dominants, which characterize them. Studying of conservatism took place in the basic within history and political science. Proceeding from love of freedom of the Russian person, and historical aspects, which had impact on his mentality it, is possible to claim that the Russian person seeks to admire force of the state instinct, spiritual loyalty, and Christian patience. In other words, the Russian person trusts in Russia hopes for the better future for it and suffers adversities of the present.

The uniqueness of any nation, demands from us more detailed studying of Russia, studying of its core values and mentality. According to I.A. Ilyin, L.I. Solonevich and L.A. Tikhomirov, for the Russian person the aspiration to freedom has to be guaranteed by the central power that he could self-express and solve internal problems at the local level, is peculiar. On the other hand, at the observance of the freedoms, he demands from the power of observance of its rights and justice.It would exclude any sort the injustice arising because of the imperfection of the law. At observance of the rights, based on justice, and freedoms it is ready to support the power, to suffer any adversities and to believe in her. The individual power which, proceeding from historical events and national mentality, is the best decision since Russia possesses weakness of the public discipline will be the best form of the government. At last, autocracy excludes race for power. It does not spray and divide, excludes fight against bodies of execution of the power that only strengthens the 
central power, allowing working more for the good of the people.

The mentality is defined as "quality of the mind characterizing certain individuals or the whole class. Kh. Sheintal and M. Lazarus note mentality as the uniform super personal consciousness that thinkers called "national spirit." The term for the first time meets in 1882 in R. Emerson's works. N. Ya. Danilevsky considered mentality as the phenomenon, which comprises the main lines of a psychological system of the people, which pass through all its history. In the XX century of M. Blondel and J. Geoffrey, continued studying of concept and found out that mentality bears in itself set of images and representations by which members of any social group are guided in behavior. Their understanding of the world and a place in it is expressed in these representations.

The mentality is staticized in various forms: world outlook, religious and creative. The religious form of mentality is staticized in beliefs, ceremonies using which the relation of people to existential problems is governed (lives and death, the good and evil, etc.) (Karabulatova et al., 2015). The creative form of mentality is realized in myths, folklore and art culture. In creativity, communication between a conscious and unconscious component of mentality is most fully shown. The public collective unconscious codes social information, transferring unconscious mental to the social unconscious. The world outlook form is expressed in total the views, judgments, concepts peculiar to the national character of people. Style of thinking as an expression of consciousness of the individual defines his consciousness. In the mentality of any nation, there are mental mechanisms representing an alloy conscious and unconscious, rational and irrational. Operation of these mental mechanisms consists in the identification of languages, the nations, and ethnic groups, ensuring outlook among people. Sociology of value interest, first, as the factor playing a part in regulation of social interactions, the fundamental element of culture, which is a basis of ideology, the valuable and standard mechanism for social regulation. They provide integration of society, helping individuals to carry out socially approved the choice of the behavior in vitally significant situations. A large number of approaches to a typology of values of conservatism, to their definitions and structure was developed. Authors based on the analysis of sociological, culturological, philosophical, sociological concepts allocates three main approaches to definition of concept of the Russian conservatism as characteristic feature of the Russian mentality, mysterious "the Russian soul".

\section{Materials and Methods}

Concrete expression of mentality as cultural universality is the mindset, which is traced, in steady set of attitude, outlooks of the personality or public group in the context of a certain ethno cultural tradition and social environment of dwelling. In this regard, we conducted sociological surveys of Russians. The empirical base of research work was made by the high quality and quantitative socio-political researches executed in 1994 - 2008 the part from which is carried out with the direct participation of authors. The mentality plays a role of the regulator of the public life of individuals and influences formation of a certain type of the "daily consciousness" defining criteria of rationality.

The basis for this study is based on the findings of leading Russian and Western scholars specializing in the study of the processes of transformation of the political system of society. The analysis was based on a combination of methods, techniques, principles applied in political and Related Sciences, especially political history, political philosophy, political sociology, and political psychology. Mental ideas and attitudes act as reference models for the choice of alternative ways of behavior of the individual, groups. Among the historical works, it is possible to distinguish the works Garbuzov V. N., Ionina L. G., Lebedeva, Yu.B., Mochkina A. N., Rakhshmir P. Yu. and others. Among politological works, it is possible to call works of Gusev V.A. , Dugina A.G., Panarina A.S., Posadsky A.V., Repnikova A.V., Shuvalova Yu.E., Chernavsky М. Yu. Идеология изучалась Herder I.G., Girts K., Iglton T.. Sociological approach to the analysis of conservatism contains in works of foreign scientists: Althusser L., Durkheim E., Collins R., Lukács D., Manheim K., Marx K., Parsons T., Engels F. Among the Russian scientists it is possible to call Andreyev E.M., Dmitriyeva A.V., Zinovyeva A.A., Mezhuyeva V. M., Mironov A.V., Slavina B. F., Toshchenko Zh.T., Chuprova V. I.

The subject of a national idea for the first time sounded at representatives of early Slavophilism Aksakov K.A. and I.S., Kireevsky I.V. and P.V., Koshelev A.I., Samarina Yu.F., Homyakova A.S. and others. In the twentieth century Slavophile paradigm emerged with Wachowski's representatives movements that define the spiritual basis of modernization processes and adequate Russian soil sociocultural of vectors of state (P. I. Novgorodtsev, P. B. Struve, S. L. Frank, N. And. Berdyaev, S. N. Bulgakov, Georges Florovsky, I. A. Ilyin, B. P. Vysheslavtsev). Wachowski thought so, is a project of conservative thinking.

L.A. Tikhomirov thoroughly worked the idea of "ethical monarchism" that essence is captured in a formula about restriction of the Supreme Power with moral. I.L. Solonevich developed the doctrine about the original beginnings of public authority, which he considered as an ideal of the Russian state system.

Methodological basis of the research form used in conjunction new institutional, structural-functional, behavior lists, 
societal-activity approaches, methods of comparative and policy analysis. The neoinstitutional approach allowed us to identify the peculiarities of functioning of the different institutions of the political system of society, to analyze the peculiarities of the institutional complexity and institutional distortions in the transformation process. Based on the interrelation of the functioning of formal and informal institutions, institutional structure and activity of the subjects of transformational activity (Kobersy et al., 2015). Relying on the principles of structurally functional approach, the author investigated the process of transformation of the political system of society at three interdependent levels: institutional, valuable and behavioral. According to the provisions behavioristic approach, the author has described the strategy of political behavior, using indicators such as the level of adaptability, the degree of formation of the system of identities, the nature of political values and attitudes. The use societal-active approach was dictated by the necessity of taking into account the inversion of the nature of socio-political dynamics that determine the specifics of the course of transformation processes aimed at both the reproduction and change of those or other structures.

\section{Results}

The trust to the power of the population is formed if the authorities consider his opinion and especially if the situation changes for the better. A third of respondents could note this fact $(36,2 \%)$ From them $16,1 \%$ noted that such facts there was some and $20,1 \%$ noted that such fact took place once. Among noted the above: the people calling themselves conservatives $(45,0 \%)$ and people, calling themselves liberals $(43,2 \%)$ are presented practically equally. It is remarkable that a third of respondents never stated the opinion to the authorities. From the people who chose this answer and calling themselves liberals (16\%) supported that it is necessary to participate in the debate of $45 \%$. In this regard, Orthodox Christians $(92,3 \%)$ never stated the most passive the opinion to the authorities.

Nevertheless, 20,3\% consider that they, undoubtedly, can have an impact on adoption by the power of these or those decisions and $27,3 \%$ consider that somewhat can affect. Among the adhering above positions of $41,3 \%$ of the people calling themselves conservatives and $58,7 \%$ of the people calling themselves liberals. $52,8 \%$ - young people and $47,2 \%$ people of advanced age.

Overall, respondents have a positive attitude towards the authorities, which can be confirmed by third-party Statistics, Polls for go, where the President's approval is 66\%; for $2013191-62 \%$ and $2014192-76 \%$. The same statistics with a high level of confidence in the study paddocks center, where the credibility of the President for the year 2009 is $63 \%$ and for $2013-55 \%$. We in our study did not share the government institutions, because for us it was unimportant this division, but it was more important to measure the degree of discontent, which would eventually be reflected in the application of radical measures and total rejection of the existing values and the transition to a liberal, as best suit their requirements. In General the public has no radical coloring and expressed only in the peaceful defense of their interests at meetings sanctioned by the authorities, i.e., it can be argued that Russians be concerned about is not some ideological course of the authorities, but their internal solutions, which can be adjusted with the active participation of citizens. Thus, a gradual departure from the imposed liberal values and return to other more traditional (as we see it from all statistics as a whole) does not consolidate the society in a radical way and was in the Russians to "go to the barricades" for the return of liberal values. On the other hand, if we analyze the data of the same Levada Center, the high rating of the President, as an institution of power, compared with the government (34\% for 2009 and $30 \%$ in 2013) or the State Duma (21\% in 2009 and 25\% for 2013)194 confirms that the factor that the Russians gravitate to the principle of autocracy and in the power of see primarily the personification in the person of the President. All this is because the traditional values of the image of power inherited in the archetypes and reproduced by both the youth and the Russians in celom, so the credibility of the President in Russia is much higher than other institutions.

Moral power. $64,8 \%$ of respondents are convinced that authorities in Russia do not bear indeed responsibility for consequences of the actions. It is declared first of all by the people carrying themselves to liberals $(68,8 \%)$, and also voting for LDPR (81,6\%), "Yabloko" (78,6\%), the KPRF (64,6\%), "Right cause" $(64,3 \%)$ of $24,6 \%$ of respondents was noted that they were the witness of a situation when authorities recognized the mistakes before the people, but a significant amount of interviewees $(75,4 \%)$ did not note this fact. Quite large number of respondents met the fact of extortion of a bribe at it or relatives from representatives of the authorities $(38,8 \%)$.

All this also corresponds to other research according to which $49 \%$ of the Russian citizens consider that modern Russian the state reflects interests of rich sectors of society and $46 \%$ that interests state byurokratii196. Thus, despite the fact that Russians in the majority support the president, they are not satisfied with domestic policy of the state, which consider as focused on a certain layer of society.

Justice.

Respondents were quite law-abiding. 55,7\% noted that the existing laws are imperfect, but they should be 
observed that the corporation did not plunge into the chaos of lawlessness. From $65,6 \%$ that chose this answer called themselves conservatives, $49,6 \%$ - liberals. $53 \%$ of respondents - youth and 53,3\% - representatives of advanced age. $70,8 \%$ voted for the CPRF. The existing laws are imperfect, but they can be bypassed for the sake of the interests, noted $33,9 \%$ of respondents. This point was supported most of all by the people calling themselves liberals $(34,4 \%)$ with the higher education (31,5\%) and the highest level of the income (40\%). The choice of a way of life not on laws, and "on conscience" was noted by only 10,4\%. These data, apparently, show quite high level of sense of justice of modern Russians, replaced, which sacramental understanding of life "on the truth", but in the following question: "whether you arrived sometime in the life "on conscience", breaking thus the law?", - 60,9\% of respondents from whom $56,9 \%$ called themselves conservatives, 63,2 liberal \% positively answer. 54,3\% youth and 64,4\%-people of advanced age. Moreover, from the people who called themselves conservatives and declared the law-abidingness, $23,3 \%$ admitted the fact of its violation for the sake of an act "on conscience", and from called themselves liberals - 46,8\%.

\section{Discussion}

Under conservatism, in fact, refers to the idea of "maintaining something in its original state". There are five main generated based on Russian and Western historical thought of approaches to the definition of conservatism, namely: as aristocratic ideology; pragmatic political opinion; situationally approach; positional approach; ideological interpretation.

According to the first approach as to aristocratic ideology - conservatism represents reactionary expressions of thoughts among a feudal agrarian aristocratic class after the French revolution where bears in itself special historical and economic implication and reflects negative attitude of the European aristocracy to changes.

According to the second approach, conservatism is considered as a form of a political pragmatism according to which it absorbs the prevailing political, cultural and economic lines, i.e. it incorporates ideas of other ideologies and conducts protective policy concerning them, if necessary. Thus, it can include liberal ideas extremely opposite each other.

Also, conservatism is considered with situational and positional points of view. In the first case, conservatism is not connected with any certain historical event or feature of consciousness of the person. It has no idea or a utopia to which it is necessary to aspire. In other words, conservatism seeks to protect only any political doctrines, which were institutionalized. Any political ideas that are outside the settled institutes and which can lead to changes - are natural enemies of conservatism.

From the point of view of "positional", it is possible to note that conservatism is connected with interpretation of human habits, values, is part of everyday life and is called as "natural conservatism". There are some approaches to "accumulation" of these values:

- The absolutism where for each society there is the unique and universal set of values, but a problem is "distinctions" in societies since their "ideality" can lead to collisions in the society;

- The relativism is considered that it is less inclined to dogmatism and "valuable" repressions;

- $\quad$ The pluralism is understood as an intermediate option between an absolutism and relativism. Can enter the list: justice, freedom, rule of law, law and order, legal and political equality, prosperity, world, politeness, happiness, etc.

- Moreover, at last, the fourth approach or ideological interpretation in which conservatism represents quite accurate ideology, which is not merely a consequence of historical events or a certain outlook of any class, but integral structure of ideas.

The Russian conservatism in the first quarter of the XIX century was related to the West European conservatism though developed rather in parallel under the influence of similar factors, than under its influence.

Historical events that shook Russia in the VIII-XIX century led to public reaction to a radical Westernization of the country. Since the reforms of Peter I, the manifestations of the extreme liberalism of Alexander I, megalomania Russian nobility, the deprivation of the Orthodox Church of its national influence, Russian conservatism was the answer conservatively configured nobility to the destruction of all indigenous customs and traditions. Unprecedented challenges gave rise to the desire to protect fundamental values.

The factors that influenced the formation of the conservative current domestic social thoughts connected with historical, geographical and national context and were subsequently reflected in the culture.

Historical events at first are connected with defeats in wars with Napoleon in 1806-1807 when the nobility was overflowed by the nationalism wave, which had accurate conservative accents. At court, conservatives held influential state posts and had a real opportunity to influence on the inside - and foreign policy decisions.

"In the first quarter of the XIX century conservative moods were issued in the concept of autocracy as manifestation of the national original Russian spirit submitting only to the truth, conscience, and God, but not any 
terrestrial forces". The fullest embodiment of the concept of autocracy of this time "The note about ancient and new Russia" supported N. M. Karamzin which basic provisions were apprehended by a galaxy of the next generation of the Russian conservatives from S. S. Uvarov to L.A. Tikhomirov.

The priority of the monarchy, a critical attitude towards the ideas of the Enlightenment, the cult of morality, control over social life proclaimed representatives of the conservative wing of the Moscow Freemasonry. Interestingly, even in Freemasonry existed carriers of the nationalist mindset that condemned Peter I's reforms destroyed as national identity (for example, Ever D. P.).

The Protestant direction of conservative thought preached cosmopolitanism state where autocratic power was understood as a political force that protects Europe from the revolutionary ideologies.

The Russian nationalist conservatism set as the purpose to preserve the traditional present, appealed to ethnic values and reconstructed the historical past of Russia as a support of national consciousness, creating mythological figures secular sacred (for example, A.V. Suvorov), helping to endure Russia the heaviest historical cataclysms.

By the beginning of the $X X$ century as a reaction to nationalist separatism tendencies in conservative ideology amplified.

In modern socio-historical thought, "... the question of the existence of uniform, conservative model remains debatable".

Besides, there is no uniform standard classification of the directions of the Russian conservatism. However, based on the analysis of the main views of theorists of conservatism it is possible to offer the following classification of his representatives.

1. Conservative Orthodox Christians churchmen (metropolitans Innokenti (Smirnov), Serafim (Glagolevsky), Filaret (Drozdov), Theophan Zatvornik, aged men of Kozelsk Optina Pustyn: Ambrose, Leonid, Makari; archimandrites Photius, Magnitsky M. L., Stanevich E.I., Smirnov S. I.).

The metropolitan Innokenti (I.D. Smirnov) proclaimed "... away of unification with Christ, full of works and feats, denied division of the church into rumors, sects, splits". The Metropolitan Serafim (S. V. Glagolevsky) also spoke on behalf for "... protection of Orthodox Church of Russia of secret societies that harm not only to church but also society and an imperial throne".

"Optina Pustyn became the spiritual center of Russia, which merit consisted that in the Russian culture, that since Petrovsky times under strong Western influence in the second half of XIX there is a gradual return to Orthodoxy. Aged men Ambrose, Leonid, and Makari, left many precepts to spiritual children, calling for patience, humility and hope for the best".

M. L. Magnitsky - the political leader, the publicist and the poet - anticipating a known formula of S. S. Uvarov: "Orthodoxy. Autocracy." the plan of "national education" constructed based on Orthodoxy and autocracy suggested Emperor Alexander I to accept a nationality. Offered idea to create "the code truly Russian" as, in his belief, the legislation existing in Russia was the result of a loan of the West European legal experience. Being the active member of the Russian Orthodox opposition, considered unacceptable the protection rendered by the power to various mystical currents getting from the West.

The political and public figure G. A. Shechkov focused the views "... on the Orthodox dogma resisting to the risen pagan world».

2. Conservatives-masons(Labzin A.F., Golenishchev-Kutuzov P. I., Pozdeev I.A., Runich D.P., Shechkov G. A.). Moscow representatives of Rosicrucianism Golenishchev-Kutuzov P. I. and Pozdeev I.A. "... recognized an ascendent position of Orthodox Church as it was the state institute that the loyal citizen has to recognize if he wants stability and order, supported rigid control over public life and moods".

"Even in Freemasonry representatives of nationalist sentiments met. So, for example, the Moscow memoirist and the writer D.P. Runich adhered to the idea of identity of Russia", geopolitical doomed to an antagonism between the West and the East. Called Russia the only country that kept the perfect system of a state system from antiquity and condemned westernized policy of the authorities as destroying Russian "national spirit". Supported return to ethical standards and traditions of the past, strengthening of a family as support of society, implicit submission and service to the corporation. The power, in his opinion, has to be the firm, not allowing distemper. Reforms - the only thing that it can be admissible, but not revolts and revolutions.

3. Conservatives-mystics-cosmopolitans (Alexander I, Golitsyn A.N.). At a certain stage of the board Alexander I and the state and public figure, the prince A.N. Golitsyn professed a social utopia of the "evangelical" or "allChristian" state. The autocratic power was thought as the tool urged to protect Europe from the blasting doctrines and revolutionary shocks extending there. In modern Russia, these ideas can be comprehended as resistance to the scenarios extending from the West "orange", "tulip" and to them similar revolutions. 
4. Conservatives-nationalists (Menshikov M. O., Kowalewski P. I., Pogodin M.P., Rostopchin F.V., Urusov A.P., Shishkov A.S., Shulgin V. V.). In views of representatives of this direction, the people were considered as the carrier of traditional moral values, unlike the elite submitted the western influence.

A.S. Shishkov - the military and the state public figure for the first time began to design national and conservative tradition. On his belief, national education has to be national and the main task of education - "... to enclose Pride of the Fatherland and love for the country in the soul of the child. S. S. Uvarov's formula "Orthodoxy. Autocracy. The nationality" goes back to Shishkov's ideas.

The political leader and the writer F.V. Rostopchin based the concept of conservatism on the self-sufficiency of Russia, its independence of Europe. Criticized the power for a hobby for ideas of cosmopolitism and lack of order in the state life.

The public figure and the publicist M.P. Pogodin connected the role with the protection of "the Russian originality ". In some works emphasized a hatred of Europe to Russia and claimed that for the rescue of the originality all Slavs have to unite in uniform state whole under the control of the Russian tsar.

5. Conservatives-liberals (Witte S.Yu., Struve P.V., Chicherin B. N.). The conservative and liberal direction of social thought, on the one hand, emphasized the traditionalism, but thus disowned from reactionary views, which were regarded as the reason for many regional and nation-wide failures.

The philosopher and the public figure B. N. Chicherin in the XIX century are designated the main directions of liberalism expressed in the public opinion. The lowest step is occupied by "street liberalism" that wants to know nothing, except own willfulness. Representatives of this type of liberalism feed irreconcilable hatred for authority. The second liberalism - oppositional, negatively criticizes the developed state of affairs, anything, without offering in exchange. His representatives keep apart from the power that does not prevent to take lucrative posts and ranks. The third type of liberalism - guarding. His representatives know country history, understand conditions of the power and are not at enmity with it. The Supreme moral law - the law of good, a personal liberty of the person it is connected with freedom of others. The power - strong, providing freedom of citizens and thought, defending public interests from anarchical.

6. Conservatives-Slavophiles (Aksakova I.S. and K.S., Belyaev I.D., Kireevsky I.V., Koshelev A.I., Samarin Yu.F., Hamsters of Ampere-second.). Slavophilism - the current defending idea of national originality and a special way of development of Russia as opposed to their opponents Westerners. In general Slavophiles sought to overcome cosmopolitism and intellectual apathy of the Russian society.

The ancestor of Slavophilism the philosopher A.S. Homyakov is considered attached paramount significance to the original development of Russia in comparison with the main European civilizations. The communality of the Russian people, tolerance, and confession of traditional Orthodox values - bases for the creation of the human society based on brotherly communications and mutual love. The individualistic consciousness of the western person is a consequence of disintegration of complete life of the spirit.

K.S. Aksakov - one of the ideologists of Slavophilism, who created "the theory of the earth and state" which became a creed of Slavophil's. In the theory, Aksakov claimed that until IX century, before the formation of the state Slavs lived the community, the earth, on the basis of the moral law of the human relations. Only external dangers compelled Slavs to create the state, which the external norms, but not a moral voice of conscience forced, people to fulfill obligations.

7. Conservatives-national (Grigoriev A.A., Dostoyevsky F.M., Strakhov N. N.). Nationalism as the direction of the Russian political thought of the second half of the XIX century was a continuation to views of Slavophiles, the public opinion trying to create in conservative spirit. The people have to be uniform with the head (at F.M. Dostoyevsky - the monarch), spiritually merged all estates alien to material benefit. The ruling elite has to finish imitation to the West and oblivion of own civilization.

8. Conservatives-geopolitics (Vandamme A.E., Danilevsky N. Ya., Dusinsky I.I., Kartsov Yu.S., Syromyatnikov S.N., Ukhtomsky E.Z.). This direction did not contain the uniform program. A search of allies in Europe was the main direction of their reflections, beginning from Slavs to French, British and Germans. The Slavic type which central place is taken by Russia, according to Danilevsky, has to, having overcome the hostile relation of the countries of the romano-German cultural and historical type, to take the taking priority place on a historical scene.

Geopolitician and Pan-Slavc Dusinsky I.I. believed that the reasonable foreign policy has to have a dual character: national (Russian) and breeding (Slavic). Territories of the Russian state still are in a formation stage. It supported Danilevsky's ideas concerning the cultural and political association of Slavs of the whole world under the auspices of Russia. The identity of the Slavic people within its territory will remain. This was 
not about Russification of Slavs, and only about the peaceful association.

The publicist Yu.S. Kartsov also shared views of Slavophiles about the identity of the Russian state formed of the center and developing towards the periphery. The government - pledge of integrity and safety, both the sovereign and all occupation layer. As the reason of exasperation of the people against the state considered degeneration of the highest aristocracy anxious with benefits of the situation.

Views of the public figure S. N. Syromyatnikov addressed to a public system of Russia, which he perceived rather east than western, and the Russian culture is closer to Chinese, Korean, Turkic that causes its particular situation in the Eurasian space. As the optimum form of government considered autocracy, and the king responsible for all citizens of the empire irrespective of their social status. The state has to develop the identity of the citizen, support his aspiration to self-development.

9. Conservatives-statesmen (llyin I.A., Skating rinks K.P., Pazukhin A.D., Pobedonostsev K.P., Solonevich I.L., Tikhomirov L.A., Tolstoy D. A., Uvarov S.S., Shevyrev S.P.). The political leader and the scientist Sergey Semenovich Uvarov made the slogan of the activity a triad: "Orthodoxy, Autocracy, and Nationality". Opposing uncontrolled Europeanization, urged to keep Russia on the beginnings, it is primordial it inherent. It understands the Orthodox belief as the belief of ancestors feeding a creative power of the people. The autocracy seems, as a support of the political existence of Russia, feeble effort to majestic life, in opinion, Uvarov, will lead to a decrease in power and weakening of internal tranquility of the country. A question of a nationality Uvarov left open, addressing his decision to educated Russian thinkers.

The historian Stepan Petrovich Shevyrev became the representative of the official ideological doctrine "Autocracy. Orthodoxy. Nationality". It interpreted this triad in the category of feelings, but not thoughts, emphasizing its innateness to the Russian national life.

The political leader Konstantin Petrovich Pobedonostsev criticized reckless loan of the western political trends, stressed that representative establishments be directly connected with the history of the country. Critically treated and procedure of elections as it plays on emotions of the crowd and not always the most professional politician wins. He did not consider that parliamentarian helps to adjust positively life of the Russian society as supporters of this idea moves either naive utopianism or aspiration to personal benefit. Experience shows that having been hit in hands the power, Democrats become still the worst bureaucrats and managers of national life. To be the state person - means to sacrifice itself to business to which you serve. In educational institutions, it is necessary to cultivate a love for the country, a family, and the moral principles. The family - a basis of the state, in it, as well as in the state is not present a place to excessive vanity and artificial requirements.

\section{Conclusion}

Based on the above it is possible to allocate universal bases of the Russian conservatism:

1. Sacralization of the autocratic power. The power is God-given and has high mission;

2. State - the highest priority and judge the man. Paternal care of the state of man and obedience to the state of the society..

- Unity of the population and the dominating elite;

- Service in freedom. The personal liberty is connected with its duties about society, the state;

- The idea of original Russian way. Russia has his historical way and transferring of foreign models of development leads to destructive consequences for the country;

- revolutions are contraindicated to the Russian society since conduct to even big social contradictions;

- Russia has to conduct independent foreign policy. Interests of the country prevail over all-European and universal;

- Ensuring economic and political security of the country. Preservation of the inalienable territory;

- the idea of the imperfection of the person, therefore, original rescue is possible only by a return to national sources.

Thus, proceeding from features of historical process it is possible to draw a conclusion that conservatism is represented the ideas that are not denying everything new, to please to traditions, and allowing changes, but - they have to happen to one key substantial aspect for the sake of advantage of society, and not just as process of changes for the sake of changes.

Thus, proceeding from the analysis of the main theoretical views of scientists of conservatism, it is possible to allocate its following fundamental values: spirituality which is understood as a support on moral and the Russian 
sociocultural traditions; the statehood meaning the strong power protecting the national sovereignty of Russia, ensuring safety of citizens and assuming responsibility for development of the country and wellbeing of the citizens); a nationality, consisting in national originality); family values, etc.,

These values still remained the main in system of priorities of Russians (a footnote. All-Russian poll. VCIOM, 15.04.2004; Project "Basic values of Russians ("A Tomsk initiative") of 2001-2002; data of VCIOM, FOMA, Institute of complex social researches of the Russian Academy of Sciences, ISPI Russian Academy of Sciences.)

Also inclination to the autocratic and personified power to what allocation of the Institute of the President against other institutes of the power and his high rating testifies, on the one hand, remained. The same can be told and about the value of justice which is put by Russians above, then the written law and its observance. Russians prefer to live more on conscience, than under the law. Moreover, at last, patriotism and perception of the Homeland as the birthplaces and lives speaks about deep communications of Russians with Russia, and all discontent with domestic policy and aspiration to the better life abroad, mainly remains only words.

Anyway, Russians, with optimism inherent in them still have belief in bright future for Russia, and the values allocated to us, which are the cornerstone of the Russian conservatism, continue to remain in consciousness of Russians and creation of new Russian ideology, which would consolidate society, can form a basis.

\section{References}

Aksakov, K.S. \& Aksakov, I.S. (1981) Literary criticism. M.

Aksakov, I.S. (2002) Why so hard life is in Russia? M.

Allison, L. (1984) Right Principles: A Conservative Philosophy of Politics. Oxford: Blackwell.

Althusser, L. (1969) For Marx. Hammondsworth.

Anisimov, A.P. \& Gulyaihin Vyacheslav N. (2013) The study of the phenomenon of "mystifying russian soul" within the context of russian history and its significance for increasing mutual understanding between the russian people and other nations. In the: Global Journal of Arts Humanities and Social Sciences Vol.1, No.3, pp. 131-145.

Beck, U. (1998) Politics of risk society/l The politics of risk society. Ed. By Jane Franklin. Polity Press.

Belenky, I.L. (2000) Rol of a geographical factor in the domestic historical process. State-of-the-art review., M.

Belkov, O.A. (2010) Russky a question in modern Russia. Polemic notes about "The Russian project"//Sense of the Great victory / under the general edition of V. N. Kuznetsov. M.: Book and business.

Berdyaev, N.A. (1990) Destiny of Russia., M.

Bulgakov, S.N. (2008) Two hails: researches about the nature of public ideals. M.: Astrel.

Bourdieu, P. (1994) Beginnings. Choses Dites. M.: Sociologos.

Witte, S.Yu. (1913) Concerning immutable laws of the state life. SPb.

Kobersy, I., Novikov, V., Shkurkin, D., \& Borisova, A. (2015). Investigation of the scope of intellectual services in the aspect of virtualizationand information economy of modern Russia. Mediterranean Journal Of Social Sciences, 6(5 S3).

Vishlenkova, E.A. (2002) Caring for the souls of citizens: religious policy in Russia the first quarter of the XIX century. Saratov.

Vozmitel, A.A. (2010) The Russian power in representations of mass consciousness//Sense of the Great victory / under the general editorship of V. N. Kuznetsov. M.: Book and business.

Gehlen, A. (1963) Studies on anthropology and sociology, Neuwied U. Berlin: Luchterhand.

Giddens, A. (1991) The Consequences of Modernity, Cambridge: Polity Press.

Girts, K. (2004) Ideology as cultural system//Girts K. Interpretation of Cultures: The translation from English M.

Eagleton, T. (1996) Ideology: An Introduction. L.

Gusev, V.A. (2001) Russky conservatism: main directions and stages of development, Tver.

Durkheim, E. (1976) The Rules of Sociological Method. New York Free Press. 1964; Durkheim E. The Elementary Form of Religions. Life. Allen \& Unwin.

Eagleton, T. (1996) Ideology: An Introduction. L.

Eisenstadt, S.N. (1961) Modernization: Protest and Change. Englewood Cliffs (N.J.).

Eisenstadt, S.N. (1976) Socialism and Tradition. Jerusalem.

Inside Right: A Study of Conservatism. London: Quartet Books.

lliyn, I.A. (1956) Our tasks. T.1 Edition of the Russian General and military Union, Paris.

Ionin, L.G. (2000) Update of conservatism. M.: Prod. House State. Un-ta - Higher School of Economics, 2010;

Gaddafi M. "The green book", M.

Karabulatova, I.S. \& Polivara, Z.V. (2013) Turkic, and Slavs: bi-polylinguism in globalization and migrations (on an example of Tumen region). In the: Middle-East Journal of Scientific Research 17 (6): 832-836..

Karabulatova, I.S., Koyche, K.K. \& Gultyaev, V.N. (2013) The Dialog of Kazakh Steppe and Russian Forest: About the Character of Turkic-Speaking Linguistic Personality on the Territory of Russian-Kazakhstani Border-Zone. In the: Middle-East Journal of Scientific Research 17 (7): 853-858.

Karabulatova, I.S., Sayfulina, F.S. \& Akhmetova, B.Z. (2013) An ethno-lingual aspect of modern functioning of Russian dialects in North 
Kazakhstan (on an example of Kostanai region). In the: World Applied Sciences Journal Issue 27 (Education, law, economics, language and communication): 137-140.

Karabulatova, I.S. \& Akhmetova B.Z. (2015) Characteristics of Social-Cultural Vitality of Modern Russian Settlements of the Former Gorky Line of Kazakhstan. In the: Mediterranean Journal of Social Science. 2015. Vol 6, No3, S4, May 2015. pp.201-206.

Karabulatova, I., Sayfulina, F., Zamalieva, L., \& Niyazova, G. (2015). Chingiz Aitmatov's Creative Works in the National Literature as a Reflection of a New Ethnic Mythology of the Soviet Period. MJSS. http://dx.doi.org/10.5901/mjss.2015.v6n6s2p155

Kekes, J. (1998) The Case for Conservatism. Ithaca, NY: Cornell University Press

Lapin, N.I. (2000) Ways of Russia: sociocultural transformations. M.

Lukaes, G. (1970) History and Class-Consciousness. Cambridge.

Mankheym, K. (1994) Ideology and utopia//Diagnosis of our time., M.

Ryazantsev, S.V., Karabulatova, I.S., Mashin, R.V., Pismennaya, E.E. \& Sivoplyasova, S.Yu. (2015) Actual problems of human trafficking in Illegal immigration in the Russian Federation. In the: Mediterranean Journal of Social Science. 2015. Vol 6, No3, S.1, May 2015. pp.: 621-626.

Ryazantsev, S.V., Karabulatova, I.S., Sivoplyasova, S.Yu., Pismennaya, E.E. \& Manshin R.V. (2015) Modern Aspects of Human Trafficking in the Context of Labor Exploitation and Irregular Labor Migration in the Russian Federation. In the: Mediterranean Journal of Social Science. 2015. Vol 6, No3, S.2, May 2015. pp.: 67-72.

Shils, E. (1961) Tradition - Essays on Modernity: The Indian situation. The Hague.

Solonevich, I.L. (2010) National monarchy. M.: Institute of the Russian Civilization.

Florovsky, G.V. (2002) Vera and culture. SPb.: Publishing house of the Russian Christian Humanitarian Institute.

Khomyakov, A.S. (1990) Complete collection composition M. 